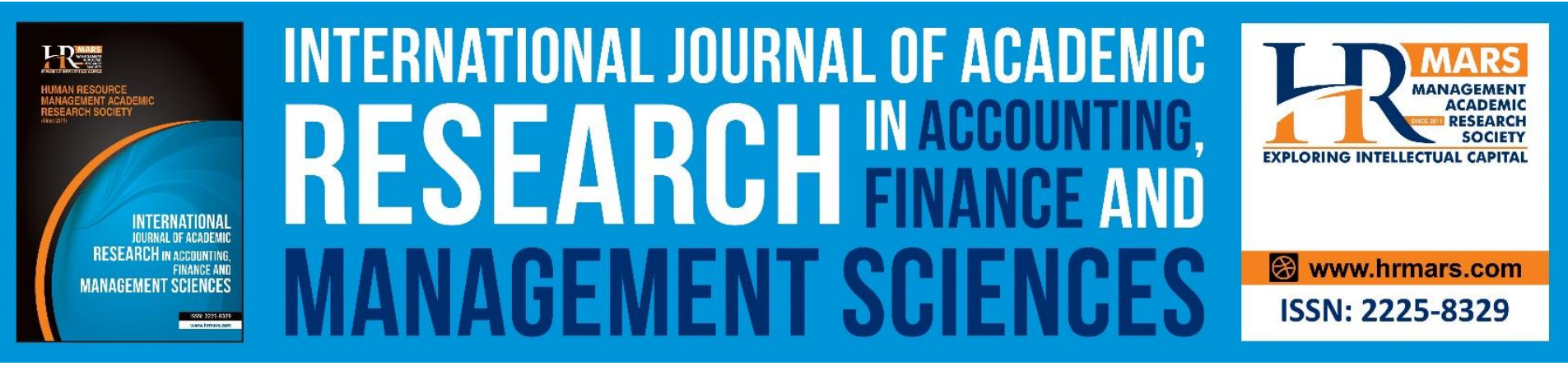

\title{
The Impact of Corporate Social Responsibility on Corporate Financial Performance from Multiple Literature Perspectives
}

\author{
Yasir S. Tabook
}

To Link this Article: http://dx.doi.org/10.6007/IJARAFMS/v11-i3/11282 DOI:10.6007/IJARAFMS /v11-i3/11282

Received: 30 July 2021, Revised: 28 August 2021, Accepted: 15 September 2021

Published Online: 26 September 2021

In-Text Citation: (Tabook, 2021)

To Cite this Article: Tabook, Y. S. (2021). The Impact of Corporate Social Responsibility on Corporate Financial Performance from Multiple Literature Perspectives. International Journal of Academic Research in Accounting Finance and Management Sciences, 11(3), 692-707.

Copyright: (c) 2021 The Author(s)

Published by Human Resource Management Academic Research Society (www.hrmars.com)

This article is published under the Creative Commons Attribution (CC BY 4.0) license. Anyone may reproduce, distribute, translate and create derivative works of this article (for both commercial and non-commercial purposes), subject to full attribution to the original publication and authors. The full terms of this license may be seen at: http://creativecommons.org/licences/by/4.0/legalcode

Vol. 11, No. 3, 2021, Pg. 692 - 707

Full Terms \& Conditions of access and use can be found at http://hrmars.com/index.php/pages/detail/publication-ethics 


\title{
The Impact of Corporate Social Responsibility on Corporate Financial Performance from Multiple Literature Perspectives
}

\author{
Yasir S. Tabook \\ Binary University of Management and Entrepreneurship, Malaysia
}

\begin{abstract}
Corporate Social Responsibility's (CSR) impact exceeds beneficiary communities to include the practitioner companies itself. That impact on business-related aspects is more obvious on the financial performance of these companies relative to non-financial performances. Thus, this has become a hot subject for literature over the past 15 years to investigate. However, these literatures ended up by an ongoing argument on the type of impact that CSR places on corporate financial performance (CFP). Therefore, this paper aims to reorganize the findings of previous studies that had tested the impact of CSR on CFP to enable upcoming researchers to accurately understand the nature of mixed or conflicting findings approached by former researchers. Thus, enhancing chances of more effective research contributions on this particular front compared to existing knowledge. In that accordance, this paper classifies concerned literature review into six categories as follows: Firstly, studies that had reported a direct or complete positive impact of CSR dimensions on CFP in general. Secondly, studies that had reported a typical impact for all or some of CSR elements on certain dimensions of CFP. Thirdly, studies that had reported occasional or conditional impact of CSR dimensions on CFP. Fourthly, studies that had reported a negative impact for CSR on CFP. Fifthly, studies that had reported a role for moderating and mediating factors on the impact of CSR on CFP. Finally, studies that had offered some explanations for the mixed results on the relationship between CSR and CFP in particular and other aspects of corporate performance in general.
\end{abstract}

Keywords: Corporate Social Responsibility (CSR), Corporate Financial Performance, Return on Assets (ROA), Return on Equity (ROE), Institutional Environment, Total Quality Management (TQM).

\section{Introduction}

Companies' acknowledgement to its responsibilities to give back to the community (Grover, 2014) and to actively work to complement the governmental role in a sort of mutual partnership (Chang \& Sam, 2015) is known by Corporate Social Responsibility (CSR). That term had evolved as a moralbased approach that had been regarded for decades as the original motive for companies to practice CSR. Thereafter, CSR was remarked as having a potential positive influence on companies' business performance. This has resulted in driving many companies worldwide to practice CSR mainly to 
INTERNATIONAL JOURNAL OF ACADEMIC RESEARCH IN ACCOUNTING, FINANCE AND MANAGEMENT SCIENCES

Vol. 11, No. 3, 2021, E-ISSN: 2225-8329 @ 2021 HRMARS

realize those business-related benefits. Therefore, these companies usually employ CSR activities as a tool or an instrument to enhance its performances in terms of profitability and business growth alongside with managing stakeholders' interests (Madueno, et al., 2016).

According to Cho and Lee (2017), corporate financial performance represents the company's value in terms of the joint effect of monetary (tangible) and non-monetary (intangible) value drivers. However, the monetary part of financial performance has received much attention by practitioners as well as by researchers in which accounting measures had been intensively applied. This has been also reflected in many of the studies that had investigated the impact of CSR activities on corporate financial performance. For example, there were many studies that had defined corporate financial performance as made of accounting-based indicators and market-based indicators (Wang, et al., 2016; Karaye, Ishak \& Che-Adam, 2014; Nollet, Filis \& Mitrokostas, 2016). However, the monetary value drivers were demonstrated while the non- monetary ones were completely neglected.

Regardless of how corporate financial performance had been measured, the majority of quantitative studies that had examined corporate social responsibility impact on corporate financial performance had approached empirical evidences for the presence of an impact for CSR practices on corporate financial performance, or as some studies referred as "corporate performance". However, the nature of that impact and its significance remained a scholarly debatable topic since the reported impact between the two constructs ranged from simply negative to strongly positive (Wang \& Sarkis, 2017). Herein, this paper intends to critically review how the impact of CSR on corporate financial performance had been addressed by previous literature, and then to classify those literatures based on its findings. That classification is expected to facilitate a better understanding of the foundation of CSR impact on companies' financial performance and the multiple perspectives shaping the nature and magnitude of that impact.

\section{Classifying Literature Review on the Impact of CSR on Corporate Financial Performance}

Apparently, scholars that had empirically examined the impact of CSR on corporate financial performance had been grouped into two main categories based on the type of that impact as positive or negative. However, the reported positive impact can be further classified as direct, indirect (moderated and/ or mediated), conditioned or limited. This sub-classification constitutes an important approach for further grouping of literature to precisely address the range of that positive impact.

In contrast, there were other studies that had reported a negative impact for CSR on corporate financial performance. Moreover, there were many studies that had offered some explanations for the mixed results on the impact of CSR on corporate financial performance in particular and other aspects of corporate performance in general. This section highlights as many valid classes of previous studies that had investigated the impact of CSR on corporate financial performance.

\section{A. Studies that had reported a direct or a complete positive impact of CSR dimensions on corporate financial performance in general:}

Literature that had reported a direct impact for CSR inputs on the corporate financial performance can be grouped into two categories according to the extent of how the impact was generalized across all the variables that had been measured. Therefore, the first category according to the researcher's review of concerned studies is the full direct impact for all CSR factors being measured on all factors of corporate financial performance as a dependent variable. 
INTERNATIONAL JOURNAL OF ACADEMIC RESEARCH IN ACCOUNTING, FINANCE AND MANAGEMENT SCIENCES

Vol. 11, No. 3, 2021, E-ISSN: 2225-8329 @ 2021 HRMARS

The second group presented studies that had approached a typical or a selective positive impact between certain factors in both sets of variables.

As an example of studies with direct and absolute positive impact for CSR on the financial performance was the study conducted by Reverte, Gomez-Melero and Cegarra-Navarro (2016). That study documented a positive and significant direct effect of CSR on organizational performance regardless of the industry's type, company's size, or the company's proactivity to do voluntary CSR. In that study, corporate performance referred basically to the corporate financial performance and the authors used monetary elements (accounting and market- based) as key indicators of that performance. However, much of the significance of that study stemmed from its inclusion of non-monetary or qualitative indicators obtained from certain management practices in the sampled companies beside the monetary measures. The results clearly highlighted the impact of CSR on the non-monetary part of the corporate financial performance that had been classified as internal and external benefits. The recorded internal benefits were mainly intangible organizational assets and capabilities such as the development of competitive know-how technologies and responsible corporate culture. Whereas the external benefits were identified to be an enhanced corporate reputation in the market in a way enabling companies to build good relations with external stakeholders and appearing as attractive employers. Furthermore, the study found companies' investments in CSR initiatives effective to increase employees' motivation, commitment, and loyalty. These findings were similar to those approached by (Sila and Cek, 2017; Wang et al., 2014). Moreover, in another study to the impact of CSR on the performance of multinational companies, Zhao, Teng and Wu (2018) acknowledged the role of CSR as an important factor in the competitiveness of these companies through enabling it to build long-term employees and consumers' trust as a basis for sustainable business models. Accordingly, that well-established employees and consumers' trust helps business leaders to create optimal environments for businesses' growth and innovation (ibid).

These results on the impact of CSR practices on the non-monetary corporate performance can be matched with the results of Vong and Wong (2013) that had also showed a direct and significant impact of CSR practices on the company financial performance. That study also found nonmonetary positive impact for the social activities conducted by companies in the gaming industry in terms of creating employment opportunities and contributing to efforts of community development as per the perceptions of community's stakeholder (ibid). Furthermore, Xiong, et al (2016) found all the social dimensions they investigated (corporate investment in stakeholders' well-being, investments in environmental protection projects, and even monetary donations made by companies) leading to higher financial performance. The study reported important managerial implications that challenged the decision makers at companies to change their perceptions toward CSR as a cost center through providing solid evidences on CSR's positive impact on the corporate overall financial performance. According to the authors, these findings should motivate companies to behave as responsible social citizens and undertake CSR as a key business related strategy (ibid).

Overall, there are many positive effects of CSR on monetary and non-monetary indicators of corporate financial performance that had been pointed out such as enhancing corporate image and reputation, developing the service quality, contributing to sustainable competitive 
Vol. 11, No. 3, 2021, E-ISSN: 2225-8329 @ 2021 HRMARS

advantage, having a better risk management, scoring high loyalty and retention rates for employees and customers, saving costs, and improving profit margins (Radhakrishnan, Chitrao \&

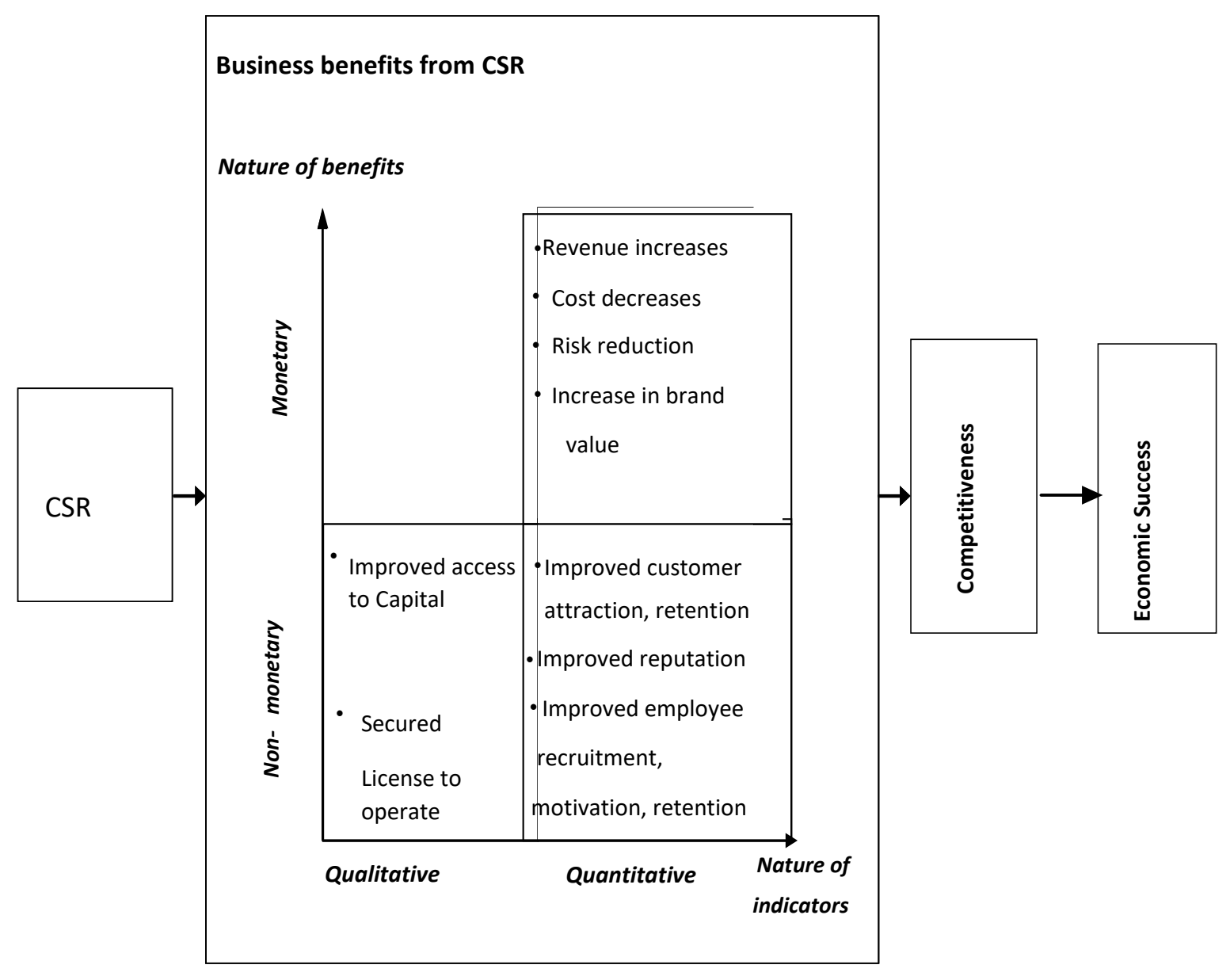

Figure 1 CSR Impact Model (Weber, 2008).

Nagendra, 2014; Gras-Gil, Manzano \& Fernández, 2016; Huang et al, 2014). For instance, the CSR impact's model developed by Weber (2008) reflected in figure 1 below provided a summary of the direct and comprehensive positive impact that CSR has on corporate financial performance in general. The model classifies CSR business's benefits according to its type as monetary and nonmonetary and the nature of possible indicators as quantitative or qualitative as related to organizational functions.

B. Studies that had reported a typical impact for all or some of CSR elements on certain dimensions of corporate financial performance:

Blasi, Caporin and Fontini (2018) executed a research to analyze the relationship between CSR activities and the economic performance -that they had measured using both market and 
INTERNATIONAL JOURNAL OF ACADEMIC RESEARCH IN ACCOUNTING, FINANCE AND MANAGEMENT SCIENCES

Vol. 11, No. 3, 2021, E-ISSN: 2225-8329 @ 2021 HRMARS

accounting-based performance indicators- for companies disaggregated by sector of activity. The researchers found that companies' engagement in CSR to have a positive impact limited to two of the market-based performance indicators which were total stock return and financial risk associated with business investments. For example, the results revealed that CSR activities increased companies' total stock returns and reduced its financial risk in almost all dimensions of CSR across all sectors the study had examined. However, the indicators of accounting-based financial performance showed unstandardized response to CSR dimensions as the interaction between the various aspects of CSR and this component of the dependent variable had been inconsistent across sectors. The authors expected that inconsistency to be the result of sectoral effects on companies' motives to practice CSR and accordingly on its potential impact on accounting based economic performance (ibid).

In contrary to the above findings, Wang, et al (2016) revealed a totally different interaction between CSR and the accounting-based indicators of corporate financial performance. In this regard, the study identified a positive and linear impact of CSR on return on assets (ROA) and earning per share (EPS) while it could not catch any reliable evidence for the existence of any impact for CSR on market-based financial performance measures such as the price-toearnings ratio $(\mathrm{P} / \mathrm{E})$ or stock return. The authors linked these results with findings of a previous study by Karaye, Ishak and Che-Adam (2014) that had suggested that the CSR-financial performance relationship appears to be more highly correlated when measured using accounting-based indicators of corporate financial performance than the market-based indicators. However, that explanation was completely rejected by the findings of Nollet, Filis and Mitrokostas (2016) that approached a conclusion of a similar impact for CSR on both accounting-based and market-based (Excess Stock Returns) performance indicators. The authors used return on assets (ROA) and earnings per share (EPS) as specific measures for the accounting-based corporate financial performance in which ROA in particular has become the most used measure of corporate financial performance by researchers (Karaye, Ishak \& CheAdam, 2014).

On another hand, Vong and Wong (2013) introduced very typical results concerning the impact of certain CSR dimensions they used to measure that construct on different indicators of corporate financial performance. The authors placed more attention on assessing the importance of CSR to the company or a certain stakeholder group from different perspectives according to value created to each beneficiary party. The study's findings reflected that some of the CSR dimensions it used like business and employment, community development, and environmental protection were positively related to three of the financial indicators applied namely revenue, market share, and overall organizational performance. In contrast, the social dimension named management social practice was found related to earnings per share and the overall organizational performance. However, the CSR dimension named responsible gambling was associated with revenue and market share (ibid). However, the researchers did not provide any explanation for that typical impact of CSR on financial performance. On a relevant context, corporate environmental responsibility is considered an essential dimension of CSR when described from sustainability perspective or corporate responsible behavior. In this regard, Benavides-Velasco, Quintana-García, and Marchante-Lara (2014) asserted that a 
INTERNATIONAL JOURNAL OF ACADEMIC RESEARCH IN ACCOUNTING, FINANCE AND MANAGEMENT SCIENCES

Vol. 11, No. 3, 2021, E-ISSN: 2225-8329 @ 2021 HRMARS

positive corporate environmental responsibility significantly affects both return on assets (ROA) and return on equity (ROE) for companies that maintain competitive environmental performance.

The individual impact of certain social dimension measures on certain financial performance indicators was also reported by Chen, Feldmann and Tang (2015) when they found a significant positive correlation between three of the measured social dimensions which were human rights, society, and product responsibility in one hand; and return on equity on the other hand. Whereas, other financial indicators like sales growth and cash flow/sales ratio were not found influenced by any of the social dimension measures.

C. Studies that had reported occasional or conditional impact of CSR dimensions on corporate financial performance:

There are also some studies that had identified a positive impact for CSR on corporate financial performance but anticipated that impact to be occasional unless further procedures been taken by companies to sustain it. An example of these studies was the one conducted by Maqbool and Zameer (2018) that had investigated the impact of CSR initiatives delivered by banks in India. The findings revealed that CSR has a positive impact on the banks' financial performance. However, the authors insisted on the importance of strategically integrating CSR's objectives in the business strategy and developing a socially oriented corporate culture to sustain the impact of CSR on the corporate's financial performance (ibid). In fact, this example sheds the light on the significance of CSR-business integration and the influence of socially oriented corporate culture.

Before presenting literature on the indirect impact of CSR on corporate financial performance, the researcher preferred to put ahead studies that have reported a direct but negative impact for CSR on financial performance. This is because part of that negative impact will be better explained after understanding the role of moderating and mediating factors that some quantitatively approached studies suggested to interfere the relationship between CSR and financial performance.

D. Studies that had reported a negative impact for CSR on corporate financial performance:

Despite the multiple benefits reported for CSR on corporate financial performance as discussed above, there are other studies that have approached reverse findings. Though literature on the impact of CSR on corporate financial or economic performance has been skewed towards a positive impact with varying differences among the studies due to methodical difference or interpretation bias as asserted by Chauhana and Amita (2014), however studies that reported reverse findings cannot be totally neglected.

For example, the results of Bhandari and Javakhadze (2017) showed that CSR reduces both accounting as well as stock-based future corporate performance. That research's findings revealed that companies with active CSR contributions tend to heavily adopt the social preference view that prioritizes stakeholders' interests over the interest of shareholders which is a common phenomenon that the Agency Theory of CSR strives to effectively control. In such cases, the executive managers or agents of these companies may strategically work to exclude any investment opportunities if not anticipated to be of much value to other 
INTERNATIONAL JOURNAL OF ACADEMIC RESEARCH IN ACCOUNTING, FINANCE AND MANAGEMENT SCIENCES

Vol. 11, No. 3, 2021, E-ISSN: 2225-8329 @ 2021 HRMARS

stakeholders even if such opportunities proved to be of high potential value to the shareholders.

On another study, Han, Zhuangxiong and Jie (2017) analyzed the data of Chinese listed companies on both the Shenzhen and Shanghai stock exchange from 2008 to 2014 using corporate document analysis. That study aimed to examine the impact of CSR on a nonaccounting financial performance indicator called product market performance to determine the actual operating conditions in the sampled companies according to recorded growths in product sales. The findings reflected that CSR activities significantly decrease the product market performance of non-state-owned companies in noncompetitive industries where the abilities of those companies to finance its debts is usually very limited. The authors attributed that negative impact to a corporate governance as an internal organizational element. That element tends to be weak in private owned companies compared to state owned ones in noncompetitive markets which gives rise to management's engagement in more self-serving purposes using many practices including CSR.

E. Studies that had reported a role for moderating and mediating factors on the impact of CSR on corporate financial performance:

As discussed earlier in the above sub-sections, the mixed findings reported on the impact of CSR on corporate financial performance implied gaining a sufficient understanding of the indirect impact that CSR may have on corporate financial performance in particular as well as on other aspects of the corporate performance. The characteristics of these moderating factors in addition to the extent and nature of its interaction either individually with CSR and multiple components of the corporate performance, or collectively in the relationship between CSR and corporate performance, require advanced investigations by CSR researchers to better redefine the relationships between these variables in the CSR context.

Among studies that highlighted the role of multi-moderating factors in the relationship between CSR and corporate financial performance was the study conducted by Javed, Rashid and Hussain (2016). That study identified a significant moderating role for dynamic business environmentswhich is almost an external factor to the organizational context- in the positive relationship the authors found between CSR and the financial performance of companies working in such environments. However, the study revealed that the manipulation of CSR activities may negatively influence that moderated relationship (ibid). The role of munificent business environments was also marked by Goll and Rasheed (2004) reporting that profitable companies can grow fast in munificent environments that are perceived effective to enhance the engagement of these companies in more CSR practices compared to environments characterized by scarce resources where companies' social performance tends to be very limited. Therefore, the authors suggested that a dynamic and munificent environment plays a significant moderating role on the relationship between corporate social responsibility practices and corporate financial performance (ibid).

On the internal organizational context, Xie et al (2017) presented other moderating factors as they found a strong moderating effect for institutional environment factor in the relationship between CSR practices and financial performance as well as in the relationship between CSR practices and customer satisfaction which may also indirectly enhance corporate financial performance. In this respect, the presence of a well-established institutional environment 
INTERNATIONAL JOURNAL OF ACADEMIC RESEARCH IN ACCOUNTING, FINANCE AND MANAGEMENT SCIENCES

Vol. 11, No. 3, 2021, E-ISSN: 2225-8329 @ 2021 HRMARS

enhances the positive relationship between CSR practices and these two variables (financial performance and customer satisfaction). The study assigned the significance of that moderating role for institutional environment to the ability of any well- established institutional environment to provide long term supporting policies and a healthy organizational culture that can be easily aligned with the corporate vision and the surrounding legal environment. In addition to its moderating effects in the relationship between CSR and corporate financial performance, institutional environment has a direct positive impact on the level of companies' engagement in CSR functions and strengthen stakeholders' perceptions about its social responsibility (ibid). These findings were also supported by Cavazotte and Chang (2016) that regarded institutional environment as an important factor that companies should understand its influence on the impact of CSR investments on financial corporate performance. This is because CSR investments are associated with financial and non-financial costs. Furthermore, it is argued that CSR impact on corporate performance ranges from negative to significant positive and is also influenced by many internal and external factors (ibid).

On another hand, Mehralian et al (2016) identified a mediating role for total quality management (TQM)- as an internal management system that usually takes into considerations the interests of various stakeholder groups - in the relationship between CSR and corporate financial performance. The corporate financial performance in that study consisted of monetary and nonmonetary items and it was measured using the Balance Score Card techniques. The mediation effect reported for TQM in the aforementioned relationship was attributed to managers' employment of that managerial tool to improve the quality of their business processes and products to satisfy the interest of multiple stakeholders' groups. As a result, they can strengthen the relationships with those stakeholders and ultimately improve corporate financial performance. The importance of TQM has been also highlighted by Wang et al (2016) as a business strategy that enables companies to acquire a superior competitive advantage through the continuous process improvement. Therefore, socially responsible companies may apply TQM techniques it developed to improve the quality of its operations and the way it implements its corporate strategies which in turn lead to improve the corporate financial performance (Benavides-Velasco, Quintana-García and Marchante-Lara, 2014).

Moreover, CSR is considered a driver to a sustainable competitive advantage as well as a sustainable quality advantage through motivating companies to implement competitive management practices such as TQM. Thus, Benavides-Velasco, Quintana-García and MarchanteLara (2014) regarded TQM in conjunction with CSR as highly potential sources for sustainable competitive advantage targeted almost by all companies. The authors found that adopting these two approaches improves the capacity of the hotels they surveyed to create shared values with different groups of stakeholders. This is because both concepts almost share the same orientation toward paying high attentions to the needs and expectations of the company's stakeholders. Furthermore, the study asserted that the level of development of corporate social responsibility is positively influenced by TQM implementation (ibid) which reflected that TQM can also play a direct positive impact on CSR and corporate performance on individual basis. In general, strategic organizational tools used by companies to enhance the competitiveness of its practices such as TQM implies carful alignment between these tools and the key corporate strategies to make the tools of common values within the company's business model. In this respect, Bocquet et al (2013) asserted that corporate financial performance (as a dependant variable of CSR) is also 
INTERNATIONAL JOURNAL OF ACADEMIC RESEARCH IN ACCOUNTING, FINANCE AND MANAGEMENT SCIENCES

Vol. 11, No. 3, 2021, E-ISSN: 2225-8329 @ 2021 HRMARS

affected by the degree of consistency that managers establish across strategic organizational and environmental elements while setting CSR implementation strategies.

From the perspective that views customers as the most important external stakeholder group to the company, Xie et al (2017) suggested a full mediation effect for customer satisfaction in the positive relationship between CSR and corporate financial performance. To enhance customer satisfaction levels in an individual socially responsible company, the study highlighted the role of good institutional environments to positively strengthen the impact of CSR practices on customer satisfaction. In other words, institutional environment played a moderating role between CSR and customer satisfaction in the mediated relationship between CSR and corporate financial performance.

Furthermore, customer satisfaction was acknowledged by García-Madariaga and Rodríguez-Rivera (2017); Jha and Cox, (2015) as a moderating variable in the relationship between CSR and corporate market value and financial performance respectively. These studies implied more corporate focus on meeting customers' needs and enhancing their loyalty levels through employing CSR practices as key tools to improve customer satisfaction when making strategic decisions and thereby improve corporate financial performance (Jha \& Cox, 2015). However, according to the CSR Stakeholder Theory, companies are expected to seek the satisfaction of all concerned stakeholders considering the significant role of stakeholders' engagement in the success of social and sustainability strategies adopted by socially responsible companies. In fact, the impact of stakeholders' engagement in the relationship between CSR and the overall corporate performance has not been sufficiently investigated by researchers yet. In this regard, Javed, Rashid and Hussain (2016) expected a moderating role for stakeholders in the relationship between CSR and corporate financial performance in particular. However, in this author's assessment, it would make a good sense to identify also other factors that may control the extent of stakeholders' engagement in line with investigating a moderating or a mediating role for such an engagement in the CSR-corporate performance relationship.

Furthermore, there are also studies that have changed the position of CSR as an independent variable in the moderated or mediated relationship with corporate financial performance. These studies reported significant moderating and mediating effects for CSR in this particular front either individually or compounded with other co-variables. For example, Wang et al (2015) suggested that CSR and brand equity together can enhance companies' market value and accordingly its financial and economic position. On another hand, García-Madariaga and Rodríguez-Rivera (2017) identified a strong mediating role for CSR in the relationship between customer satisfaction and corporate reputation in both directions. These CSR-moderated and mediated relationships lead over time to significant improvements in the financial aspect of the corporate performance. More interestingly, CSR was also found a motivator to companies' ethical practices. For example, Laguir, Stagliano and Elbaz (2015) pointed out a significant influence for CSR on the level of companies' tax aggressiveness that had been defined in that study as the process of encompassing all tax planning activities either legally or illegally which represents an irresponsible corporate behavior. The study found that, the higher the level of the CSR social dimension at an individual company, the lower the level of tax aggressiveness or the higher is its ethical obligation concerning financial aspects. In contrast, the higher the level of CSR economic dimensions, the higher the level of that company's engagement in tax aggressiveness practices. The study highlighted that the level of companies' commitments to a 
INTERNATIONAL JOURNAL OF ACADEMIC RESEARCH IN ACCOUNTING, FINANCE AND MANAGEMENT SCIENCES

Vol. 11, No. 3, 2021, E-ISSN: 2225-8329 ๑ 2021 HRMARS

certain CSR dimension is a good determinant of the level of its ethical conduct to certain stakeholder groups as the impact tends to vary across different dimensions of CSR (ibid).

On a limited scope of CSR, corporate environmental responsibility -which is defined as one of key dimensions of CSR or sustainability - was empirically found by Li et al (2017) to be of significant positive influence on the corporate financial performance. However, the study pointed out that relationship was significantly moderated by the level of stringency of government regulation. For example, the more stringent government regulation is, the more significantly positive is the impact of corporate environmental responsibility on the corporate financial performance. In contrast, organizational slack had been found playing a negative moderating role in the relationship between the mentioned constructs. The organizational slack is a term that is used to refer to access in resources (usually financials) available to an individual company other than those necessary to achieve immediate business and operational requirements. In other words, the positive environmental performance of companies with abundant organization slack does not allow these companies to enhance its financial performance. However, the findings revealed that the negative moderating effects of organizational slack in this relationship can be significantly weakened by stringent government regulation. The study demonstrated that this duplicated moderating effect of stringent government regulation represents a key motivation tool for companies to improve its environmental performances, especially if those companies have few or reasonable organization' slacks and working in environments controlled by stringent government regulations. However, these findings may not be generalizable to other dimensions of CSR especially the social one that requires a working environment with limited stringency in government regulations to be of more positive influence on the three aspects of corporate sustainability performance. In this respect, this research supported literature that argued on the importance of measuring each of the CSR main dimensions individually instead of aggregating those dimensions into a single measure to accurately identify the impact of each dimension and avoid losing any important information (Laguir, Stagliano \& Elbaz, 2015).

F. Studies that had offered some explanations for the mixed results on the relationship between CSR and corporate financial performance in particular and other aspects of corporate performance in general:

Given the previously discussed findings of Wang et al (2015), that study had provided a remarkable contribution to CSR literature on the relationship between CSR and corporate financial performance despite its shortage to address any impact for CSR on market-based indicators of the corporate financial performance. For instance, the authors confirmed in their study to international construction companies over a seven years' period, that there is a curvilinear relationship between the two constructs that had been anticipated by previous researchers but had not been tested before. The authors simplified that U-shape relationship as follow: at low levels of social practices; companies will not be eligible to achieve any remarkable financial benefits since the cost of conducting such activities will be more than the foreseen gains. This stage can provide a logical explanation to the negative impact that shows up when measuring CSR impact on the financial performance that had been reported by some research as communicated above. However, the $U$ shape impact suggests that as these companies 
keep improving its CSR activities, it will financially approach a breakeven point and will start realizing increasing financial benefits as it passes that point in which CSR benefits offset the associated costs. The authors suggested that the curvilinear relationship between CSR and financial performance in the international construction industry is also applicable to other industries, where the relationship between costs and benefits of CSR similarly apply. The findings of that study implied that companies should be sufficiently motivated to improve its CSR strategies further and allocate enough financial and non-financial resources to run its CSR programs since the CSR impact is of mutual values between companies and the society though it may take some time to pay back. Moreover, the reported curvilinear relationship between these two constructs necessitated setting a regulated starting point by policy makers from where companies' commitment to CSR should commence.

In this author's opinion, in addition to using the indicated threshold in the said curvilinear relationship as a time factor breakeven point, there is also a logical suggestion to set another point but to be in a time free mode to differentiate between ad hoc CSR activities and strategic CSR activities that have been described above. Under that point, any individual company should not be able to generate any valuable benefits from causal or standalone CSR programs falling below the suggested strategic commencement point no matter how much time it takes considering that the CSR spending in such situations would most likely remain cost ineffective.

On an alternative hand, Reverte et al (2016) provided a more extended explanation to the source of the mixed findings on the impact of CSR on corporate financial performance and attributed that to two main reasons. The first reason was related to differences of measurement methods of corporate financial performance being applied by researchers. For example, some studies had focused on measuring the financial performance using accounting based indicators only. While others had applied only market based measures. On another hand, a third group of studies had applied both of these financial performance indicators. Furthermore, there was a high tendency to adopt monetary measures (accounting or market based measures) over the non-monetary measures that many studies had identified as an original component of corporate financial performance (ibid). Moreover, this author has noticed while reviewing those studies that there was inconsistency in the way of measuring some accounting based indicators such as profitability. This has been noticed in the method adopted by Chauhana and Amita (2014) to measure profitability when testing the relationship between CSR and corporate profitability. The researchers had used indicators more suiting per-unit analysis of profitability and capital budgeting instead of using more accurate profitability ratios that capture the full economic value added by the company such as return on assets, return on equity, return on invested capital, and return on capital employed (Segal, 2019).

The second reason according to (Reverte, Gomez-Melero \& Cegarra-Navarro, 2016) was the low attention paid to potential mediating and/or moderating effect of other internal and external factors that may direct or influence the relationship between CSR and corporate financial performance (ibid). There were few studies that had measured 
INTERNATIONAL JOURNAL OF ACADEMIC RESEARCH IN ACCOUNTING, FINANCE AND MANAGEMENT SCIENCES

Vol. 11, No. 3, 2021, E-ISSN: 2225-8329 @ 2021 HRMARS

the influence of mediating and moderating variables in this relationship. Therefore, this implies conducting extended investigations that acquire more internal and external factors of potential indirect influence on the direction and significance of the assumed relationship between CSR and companies' financial performance.

Furthermore, this author noticed that some studies were tackling CSR as a lump sum factor without considering the wide differences between philanthropic versus strategic CSR (Maqbool and Zameer, 2018), or proactive versus reactive CSR. Therefore, the measured impact of CSR becomes of conflicting outcomes because the perspective from which CSR should be defined had not been sufficiently considered. This was happening despite the common agreement of the majority of CSR literature that CSR as a term consists of multiple dimensions and can be defined and measured using many different perspectives. Therefore, understanding the ins and outs of the above mentioned reasons may put a logical end for the debate over the nature of CSR impact on corporate financial performance.

\section{Conclusion}

CSR has an impact on corporate financial performance. However, literature showed mixed results when measuring that impact in terms of type and characteristics due to many organizational and external factors intervening that impact or the way the constructs had been measured. Therefore, it is important to understand how researchers had tackled these factors while examining the impact of CSR on corporate financial performance. That understanding allows upcoming researchers to accurately identify the position from which the said impact had been measured or evaluated; and therefore obtain the right explanations to diverse findings on the same issue to make useful contribution to knowledge.

\section{The Study Contribution}

This study has theoretically contributed to the knowledge base on CSR field by extending the understanding on the impact of CSR on corporate financial performance to be classified as positive, negative, direct, indirect, conditioned and typical. That extended classification implies the adoption of the most accurate measurement tools and to identify clearly-defined variables. Thus, approaching reliable findings that are sufficiently logical to explain the nature or the extent of CSR impact on corporate financial performance under each of the above classified relationships between both variables. Furthermore, the study offers a conceptual mapping between CSR and corporate financial performance based on a multi-dimensional factors that is useful for future researchers to use in order to enhance the quality of their research methodologies and the reliability of their findings.

\section{References}

Benavides-Velasco, C., A., Quintana-García, C., \& Marchante-Lara, M. (2014). Total quality management, corporate social responsibility and performance in the hotel industry. International Journal of Hospitality Management, 41, 77-87.

http://dx.doi.org/10.1016/j.ijhm.2014.05.003

Bhandari, A., \& Javakhadze, D. (2017). Corporate social responsibility and capital allocation efficiency. Journal of Corporate Finance, 43, 354-377. http://dx.doi.org/10.1016/j.jcorpfin.2017.01.012 
INTERNATIONAL JOURNAL OF ACADEMIC RESEARCH IN ACCOUNTING, FINANCE AND

MANAGEMENT SCIENCES

Vol. 11, No. 3, 2021, E-ISSN: 2225-8329 @ 2021 HRMARS

Blasi, S., Caporin, M., \& Fontini, F. (2018). A Multidimensional Analysis of the Relationship Between Corporate Social Responsibility and Firms' Economic Performance. Ecological Economics, 147, 218-229. https://doi.org/10.1016/j.ecolecon.2018.01.014

Bocquet, R., Bas, C. L., Mothe, C., \& Poussing, N. (2013). Are firms with different CSR profiles equally innovative? Empirical analysis with survey data. European Management Journal, 31, 642-654. http://dx.doi.org/10.1016/j.emj.2012.07.001

Cavazotte, F., \& Chang, N., C. (2016). Internal Corporate Social Responsibility and Performance: A Study of Publicly Traded Companies. BAR - Brazilian Administration Review, 13 (4), 1-19. http://dx.doi.org/10.1590/1807-7692bar2016160083

Chang, C-H., \& Sam, A.G. (2015). Corporate environmentalism and environmental innovation. Journal of Environmental Management, 153, 84-92. http://dx.doi.org/10.1016/j.jenvman.2015.01.010

Chauhan, S., \& Amit. (2014). A relational study of firm's characteristics and CSR expenditure. Procedia Economics and Finance, 11, 23 - 32. http://dx.doi.org/10.1016/S22125671(14)00172-5

Chen, L., Feldmann, A., \& Tang, O. (2015). The relationship between disclosures of corporate social performance and financial performance: Evidences from GRI reports in manufacturing industry. Int. J. Production Economics, 170, 445-456. http://dx.doi.org/10.1016/j.ijpe.2015.04.004

Cho, S. Y., \& Lee, C. (2017). Managerial Efficiency, Corporate Social Performance, and Corporate Financial Performance. Journal of Business Ethics. https://doi.org/10.1007/s10551-017-3760-7

García-Madariaga, J., \& Rodríguez-Rivera, F. (2017). Corporate social responsibility, customer satisfaction, corporate reputation, and firms' market value: Evidence from the automobile industry. Spanish Journal of Marketing - ESIC, 21(1), 39-53.

http://dx.doi.org/10.1016/j.sjme.2017.05.003

Goll, I., \& Rasheed, A. A. (2004). The moderating effect of environmental munificence and dynamism on the relationship between discretionary social responsibility and firm performance. Journal of Business Ethics, 49(1), 41.

Gras-Gil, E., Manzano, M., P., \& Fernández, J., H. (2016). Investigating the relationship between corporate social responsibility and earnings management: Evidence from Spain. Business Research Quarterly, 19(4), 289-299. http://dx.doi.org/10.1016/j.brq.2016.02.002

Grover, A. (2014). Importance of CSR in Inclusive Development. Procedia - Social and Behavioral Sciences, 157, 103 - 108. http://dx.doi.org/10.1016/j.sbspro.2014.11.013

Han, W., Zhuangxiong, Y., \& Jie, L. (2017). Corporate social responsibility, product market competition, and product market performance. International Review of Economics and Finance $x x x, 1-17$. http://dx.doi.org/10.1016/j.iref.2018.03.019

Huang, C-C., Yen, S-W., Liu, C-Y., \& Huang, P. (2014). The Relationship Among Corporate Social Responsibility, Service Quality, Corporate Image and Purchase Intention. International Journal of Organizational Innovation (Online), 6(3), 68-84.

Javed, M., Rashid, M., A., \& Hussain, G. (2016). When does it pay to be good e A contingency perspective on corporate social and financial performance: would it work? Journal of Cleaner Production, 133, 1062-1073. http://dx.doi.org/10.1016/j.jclepro.2016.05.163

Jha, A., \& Cox, J. (2015). Corporate social responsibility and social capital. Journal of Banking \& Finance, 60, 252-270. http://dx.doi.org/10.1016/j.jbankfin.2015.08.003

Karaye, Y., I., Ishak, Z., \& Che-Adam, N. (2014). The mediating effect of stakeholder influence capacity on the relationship between corporate social responsibility and corporate financial 
INTERNATIONAL JOURNAL OF ACADEMIC RESEARCH IN ACCOUNTING, FINANCE AND

MANAGEMENT SCIENCES

Vol. 11, No. 3, 2021, E-ISSN: 2225-8329 ๑ 2021 HRMARS

performance. Procedia - Social and Behavioral Sciences, 164, 528 - 534. http://dx.doi.org/10.1016/j.sbspro.2014.11.142

Laguir, I., Stagliano, R., \& Elbaz, J. (2015). Does corporate social responsibility affect corporate tax aggressiveness? Journal of Cleaner Production, 107, 662-675.

http://dx.doi.org/10.1016/i.jclepro.2015.05.059

Li, D., Cao, C., Zhang, L., Chen, X., Ren, S., \& Zhao, Y. (2017). Effects of corporate environmental responsibility on financial performance: The moderating role of government regulation and organizational slack. Journal of Cleaner Production166, 1323-1334.

http://dx.doi.org/10.1016/j.jclepro.2017.08.129

Madueño, J., H., Jorge, M., L., Conesa, I., M., \& Martínez-Martínez, D. (2016). Relationship between corporate social responsibility and competitive performance in Spanish SMEs: Empirical evidence from a stakeholders' perspective. Business Research Quarterly, 19(1), 55-72. http://dx.doi.Org/10.1016/j.brq.2015.06.002

Maqbool, S., \& Zameer, M., N. (2018). Corporate social responsibility and financial performance: An empirical analysis of Indian banks. Future Business Journal, 4, 84-93.

https://doi.org/10.1016/j.fbj.2017.12.002

Mehralian, G., Nazari, J., Zarei, L., \& Rasekh, H., R. (2016). The effects of corporate social responsibility on organizational performance in the Iranian pharmaceutical industry: The mediating role of TQM. Journal of Cleaner Production, 135, 689-698.

http://dx.doi.org/10.1016/j.jclepro.2016.06.116

Nollet, J., Filis, G., \& Mitrokostas, E. (2016). Corporate social responsibility and financial performance: A non-linear and disaggregated approach. Economic Modelling, 52, 400-407. http://dx.doi.org/10.1016/j.econmod.2015.09.019

Radhakrishnan, S., Chitrao, P., \& Nagendra, A. (2014). Corporate Social Responsibility (CSR) in Market Driven Environment. Procedia Economics and Finance, 11, 68 - 75.

http://dx.doi.org/10.1016/S2212-5671(14)00177-4

Reverte, C., Gomez-Melero, E., \& Cegarra-Navarro, J., G. (2016). The influence of corporate social responsibility practices on organizational performance: evidence from Eco-Responsible Spanish firms. Journal of Cleaner Production, 112, 2870-2884.

http://dx.doi.org/10.1016/j.jclepro.2015.09.128

Segal, T. (2019). Profitability Ratio Indicators. https://www.investopedia.com/university/ratios/profitability-indicator/

Sila, I., \& Cek, K. (2017). The Impact of Environmental, Social and Governance Dimensions of Corporate Social Responsibility on Economic Performance: Australian Evidence. Procedia Computer Science, 120, 797-804. http://dx.doi.org/10.1016/j.procs.2017.11.310

Vong, F., \& Wong, I. A. (2013). Corporate and social performance links in the gaming industry. Journal of Business Research, 66, 1674-1681. http://dx.doi.org/10.1016/j.jbusres.2012.12.014

Wang, W-K., Lu, W-M., Kweh, Q., \& Lai, H-W. (2014). Does corporate social responsibility influence the corporate performance of the U.S telecommunications industry? Telecommunications Policy, 38, 580-591. http://dx.doi.org/10.1016/j.telpol.2014.01.004

Wang, D., H-M., Chen, P-H., Yu, T., H-K., \& Hsiao, C-Y. (2015). The effects of corporate social responsibility on brand equity and firm performance. Journal of Business Research, 68, 22322236. http://dx.doi.org/10.1016/j.jbusres.2015.06.003 
INTERNATIONAL JOURNAL OF ACADEMIC RESEARCH IN ACCOUNTING, FINANCE AND

MANAGEMENT SCIENCES

Vol. 11, No. 3, 2021, E-ISSN: $2225-8329$ @ 2021 HRMARS

Wang, H., Lu, W., Ye, M., Chau, K.W., \& Zhang, X. (2016). The curvilinear relationship between corporate social performance and corporate financial performance: Evidence from the international construction industry. Journal of Cleaner Production, 137, 1313-1322. http://dx.doi.org/10.1016/j.jclepro.2016.07.184

Wang, Z., \& Sarkis, J. (2017). Corporate social responsibility governance, outcomes, and financial performance. Journal of Cleaner Production, 162, 1607-1616.

http://dx.doi.org/10.1016/j.jclepro.2017.06.142

Weber, M. (2008). The business case for corporate social responsibility: A company-level measurement approach for CSR. European Management Journal, 26, 247-261. http://dx.doi.org/10.1016/j.emj.2008.01.006

Xie, X., Jia, Y., Meng, X., \& Li, C. (2017). Corporate social responsibility, customer satisfaction, and financial performance: The moderating effect of the institutional environment in two transition economies. Journal of Cleaner Production, 150, 26-39.

http://dx.doi.org/10.1016/j.jclepro.2017.02.192

Xiong, B., Lu, W., Skitmore, M., Chau, K. W., \& Ye, M. (2016). Virtuous nexus between corporate social performance and financial performance: a study of construction enterprises in China. Journal of Cleaner Production, 129, 223-233. http://dx.doi.org/10.1016/j.jclepro.2016.04.078

Zhao, H., Teng, H., \& Wu, Q. (2018). The effect of corporate culture on firm performance: Evidence from China. China Journal of Accounting Research, 11, 1-19.

https://doi.org/10.1016/j.cjar.2018.01.003 